\title{
PENYELESAIAN WANPRESTASI DALAM PERJANJIAN KREDIT DENGAN JAMINAN FIDUSIA PADA PT BANK PERKREDITAN RAKYAT KITA DI BADUNG*
}

\author{
Oleh \\ Ida Bagus Gede Manu Widnyana Pemaron** \\ Ida Bagus Putra Atmadja*** \\ Program Kekhususan Hukum Bisnis Fakultas Hukum \\ Universitas Udayana
}

\begin{abstract}
ABSTRAK
Perjanjian kredit mempunyai fungsi penting untuk mengurangi resiko tidak dipenuhinya kewajiban (Wanprestasi) oleh debitur. Didalam perjanjian kredit perlu adanya sebuah jaminan fidusia, dimana jaminan fidusia tersebut digunakan untuk mengurangi kerugian. Dalam hal debitur tidak memenuhi kewajiban atau wanprestasi.

Jenis Penelitian ini adalah penelitian hukum empiris dengan sumber data primer berupa data penelitian yang diperoleh melalui wawancara. Serta ditunjang dengan data sekuder berupa permasalahan yang ada.

Hasil penelitian dan pembahasan menunjukkan bahwa terdapat akibat hukum beserta upaya penyelesaian wanprestasi yang dilakukan secara kekeluargaan dan pemberian surat peringatan, beserta upaya pelelangan jaminan fidusia.
\end{abstract}

\section{Kata Kunci : Penyelesaian Wanprestasi, Perjanjian Kredit, Jaminan Fidusia}

${ }^{*}$ Karya ilmiah ini merupakan Ringkasan Skripsi yang ditulis oleh penulis atas bimbingan Pembimbing I skripsi Ida Bagus Putra Atmadja,SH.,MH dan Pembimbing II A.A Sagung Wiratni Darmadi, SH.,MH

${ }^{* *}$ Penulis pertama dalam karya ilmiah ini ditulis oleh Ida Bagus Gede Manu Widnyana Pemaron (1516051203), Korespondensi dengan E-Mail : Idabagusmanu @gmail.com

${ }^{* * *}$ Penulis kedua dalam penulisan karya ilmiah ini Ida Bagus Putra Atmadja,SH.,MH merupakan dosen Pengajar Fakultas Hukum Universitas Udayana 


\begin{abstract}
Credit agreements have an important function to reduce the risk of not meeting obligations (Default) by the debtor. In the credit agreement there needs to be a fiduciary guarantee, where the fiduciary guarantee is used to reduce losses. In the event that the debtor does not fulfill the obligation or default.

This type of research is empirical legal research with primary data sources in the form of research data obtained through interviews. And supported by secondary data in the form of existing problems.

The results of the research and discussion show that there are legal consequences along with efforts to resolve defaults conducted in a family manner and the provision of warning letters, along with efforts to auction fiduciary guarantees.
\end{abstract}

\title{
Keywords: Default Settlement, Credit Agreement, Fiduciary Guarantee
}

\section{PENDAHULUAN}

\subsection{Latar Belakang}

Perkembangan yang terjadi di Indonesia saat ini sedang berada di berbagai bidang salah satunya bidang ekonomi. Pembangunan ekonomi di Indonesia memerlukan dana yang besar dalam menciptakan keadaaan masyarakat yang sejahtera, adil, dan makmur berdasarkan Undang-Undang Dasar 1945 (Selanjutnya disebut dengan UUD 1945) yang merupakan tujuan dari Negara Republik Indonesia. Pembangunan ekonomi di Indonesia secara tidak langsung membuat pendapatan masyarakat meningkat. Namun, tidak keseluruhan hasil dari pekerjaan tersebut dapat memenuhi kebutuhan manusia sehari-hari, dimana tidak adanya batasan kemauan manusia dalam memenuhi kebutuhannya. Salah Satu solusi untuk memenuhi kebutuhan ekonomi masyarakat, dengan adanya suatu lembaga keuangan 
maupun Perusahaan Perbankan, dapat membantu masyarakat memenuhi kebutuhan yang belum terpenuhi.

Secara Yuridis berdasarkan Undang-Undang Republik Indonesia Nomor 10 Tahun 1998 tentang Perubahan atas UndangUndang Nomor 7 Tahun 1992 tentang Perbankan (Selanjutnya disebut UU NO. 10 Tahun 1998 tentang Perbankan) pasal 1 angka 2 menyatakan bahwa "Bank adalah badan usaha yang menghipun dana dari masyarakat dalam bentuk simpanan dan menyalurkannya kepada masyarakat dalam bentuk kredit dan atau bentuk-bentuk lainnya dalam rangka meningkatkan taraf hidup rakyat banyak". ${ }^{1}$ Bank dapat diartikan sebagai Lembaga keuangan yang kegiatan usahanya menghimpun dana dari masyarakat dan menyalurkan kembali dana tersebut ke masyarakat dan memberikan jasa lainnya seperti kredit. ${ }^{2}$

Bank didalam memberikan kreditnya berdasarkan pada persetujuan atau kesepakatan pinjam meminjam antara bank dengan pihak lain yang mewajibkan pihak peminjam untuk melunasi utangnya setelah jangka waktu yang disepakati dengan pemberian bunga. Perjanjian menurut ketentuan Pasal 1313 KUHPerdata didefinisikan sebagai berikut: "Perjanjian adalah suatu perbuatan hukum dengan mana satu orang atau lebih saling mengikatkan dirinya terhadap satu orang atau lebih". Didalam pelaksanaannya kredit dapat diberikan dengan jaminan atau tanpa jaminan. Kredit tanpa jaminan sangatlah beresiko dan membahayakan posisi bank, mengingat jika nasabah mengalami kesulitan dalam memenuhi prestasinya, maka bank akan sulit menutupi kerugian yang ditimbulkan terhadap kredit yang disalurkan. Kewajiban untuk menyerahkan jaminan kredit oleh

\footnotetext{
${ }^{1}$ Sentosa Sembiring, 2012, Hukum Perbankan, CV Mandar Maju, Bandung, h. 3

${ }^{2}$ Hermansyah, 2006, Hukum Perbankan Nasional Indonesia, Kencana, Jakarta, h. 3
} 
pihak peminjam dalam rangka pinjaman uang sangat terkait dengan kesepakatan diantara pihak-pihak yang melakukan perjanjian kredit. Pada umumnya, pihak kreditur mensyaratkan adanya jaminan utang sebelum memberikan kredit kepada pihak peminjam. Sementara itu, keharusan penyerahan jaminan utang tersebut sering pula diatur dan diisyaratkan oleh peraturan intern pihak pemberi kredit dan oleh peraturan perundang-undangan yang berlaku. ${ }^{3}$

Berdasarkan latar belakang masalah di atas, dapat ditemukan beberapa pertanyaan untuk dikemukakan yang tertuang didalam tulisan yang berjudul "PENYELESAIAN WANPRESTASI DALAM PERJANJIAN KREDIT DENGAN JAMINAN FIDUSIA PADA PT BANK PERKREDITAN RAKYAT KITA DI BADUNG".

\subsection{Rumusan Masalah}

1. Akibat Hukum Bagi Debitur yang Melakukan Wanprestasi Dengan Menggunakan Jaminan Fidusia pada Bank Perkreditan Kita

2. Upaya Kreditur Dalam Penyelesaian Wanprestasi Perjanjian Kredit yang Dilakukan Oleh Pihak Debitur dengan Jaminan Fidusia pada Bank Perkreditan Kita

\subsection{Tujuan Penulisan}

Untuk Mengetahui dan Memahami bagaimana cara penyelesaian wanprestasi yang dilakukan oleh pihak debitur yang menggunakan jaminan fidusia pada Bank Perkreditan Rakyat Kita.

\footnotetext{
${ }^{3}$ M. Bahsan, 2015, Hukum Jaminan dan Jaminan Kredit Perbankan Indonesia, PT Raja Grafindo Persada, Jakarta, h. 3
} 


\section{ISI MAKALAH}

\subsection{Metode Penelitian}

Jenis penelitian dalam penulisan penelitian Jurnal hukum ini termasuk kedalam penelitian hukum empiris. Dalam penelitian hukum empiris, hukum dikonsepkan sebagai suatu gejala empiris yang dapat diamati di kehidupan nyata. Empiris merupakan penelitian terhadap identifikasi hukum berdasarkan hukum yang berlaku dalam masyarakat. Dalam hal ini adanya implementasi yang sesuai antara teori dan fakta yang ada. ${ }^{4}$

\subsection{Hasil Dan Analisis}

\subsubsection{Akibat Hukum Bagi Debitur yang Melakukan Wanprestasi Dengan Menggunakan Jaminan Fidusia pada Bank Perkreditan Kita}

Akibat Hukum, Debitur Wanprestasi dilakukan penilaian terlebih dahulu yaitu pemberian surat pemberitahuan pembayaran kredit hinggap surat tegguran SP1-SP3. Jika hal tersebut telah dilanggar maka Debitur ditetapkan wanprestasi dari perjanjian kreditnya diatur pada Pasal 1238 KUH Perdata, yang menyebutkan Debitur dinyatakan lalai dengan surat perintah, atau dengan akta sejenis itu, atau berdasarkan kekuatan dari perikatan sendiri, yaitu bila perikatan ini mengakibatkan debitur harus dianggap lalai dengan lewatnya waktu yang ditentukan. Berdasarkan Pasal 1238 KUH Perdata terdapat 3 unsur yang dapat digunakan sebagai penentu debitur tersebut wanprestasi yaitu dengan surat perintah, dengan akta sejenis itu, atau berdasarkan kekuatan dari perikatan sendiri (isi dari perikatan

\footnotetext{
${ }^{4}$ Zainuddin Ali, 2009, Metode Penelitian Hukum, Sinar Grafika, Jakarta, h. 19
} 
tersebut). Jika ketentuan pada Pasal 1238 telah dilakukan debitur maka akibat hukum yang terjadi ialah :

1. Dilihat dari pada Pasal $1243 \mathrm{KUH}$ Perdata menyatakan bahwa "Penggantian biaya, kerugian dan bunga karena tidak dipenuhinya suatau perikatan mulai diwajibkan, bila debitur, walaupun telah dinyatakan lalai, tetap lalai untuk memenuhi perikatan itu, atau jika sesuatu yang harus diberikan atau dilakukannya hanya dapat diberikan atau dilakukannya dalam waktu yang melampaui waktu yang telah ditentukan". Maksud dari pasal diatas menyatakan seseorang haruslah mengganti rugi, ganti rugi tersebut berupa biaya, rugi dan bunga. Penentuan penghitungan ganti rugi tersebut dilihat dari ada tidaknya jangka waktu yang digunakan sebagai patokan kelalaian salah satu pihak. 5

2. Dilihat dari Pasal 1266 KUH Perdata menyatakan bahwa "Syarat batal dianggap selalu dicantumkan dalam persetujuan yang timbal balik, andaikata salah satu pihak tidak memenuhi kewajibannya. Dalam hal demikian persetujuan tidak batal demi hukum, tetapi pembatalan harus dimintakan kepada pengadilan. Permintaan ini juga harus dilakukan, meskipun syarat batal mengenai tidak dipenuhinnya kewajiban dinyatakan di dalam persetujuan. Jika syarat batal tidak dinyatakan dalam persetujuan, maka Hakim dengan melihat keadaan, atas permintaan tergugat, leluasa memberikan suatu jangka waktu untuk memenuhi kewajiban, tetapi jangka waktu itu tidak boleh lebih dan

\footnotetext{
${ }^{5}$ Ahmadi Miru dan Sakka pati, 2016, Hukum Perikatran Penjelasan Makna Pasal 1233 sampai 1456 BW, Rajawali Pers, Jakarta, h. 12.
} 
satu bulan". Maksud dari pasal diatas kreditur dapat menuntut pembatalan perikatannya melalui Hakim.

3. Dilihat dari Pasal $1237 \mathrm{KUH}$ Perdata menyatakan bahwa "Pada suatu perikatan untuk memberikan barang tertentu, barang itu menjadi tanggungan kreditur sejak perikatan lahir. Jika debitur lalai untuk menyerahkan barang yang bersangkutan maka barang itu semenjak perikatan dilakukan, menjadi tanggungannya. Pasal diatas hanya dapat dipakai pada perjanjian sepihak, seperti penghibahan dan perjanjian pinjam pakai, dan pasal ini tidak dapat digunakan pada perjanjian timbal balik". Artinya resiko dalam perjanjian ini ditanggung sepenuhnya oleh kreditur, debitur dalam hal ini tidak wajib memenuhi prestasinya.

4. Dilihat dari Pasal 1267 KUH Perdata menyatakan bahwa "Pihak yang terhadapnya perikatan tidak dipenuhi, dapat memilih: memaksa pihak yang lain untuk memenuhi persetujuan, jika hal itu masih dapat dilakukan, atau menuntut pembatalan persetujuan, dengan penggantian biaya, kerugian dan bunga". Maksud dari pasal diatas, debitur diwajibkan memenuhi perjanjian beserta kerugian, dan/atau dilakukan pembatalan perjanjian yang disertai pembayaran ganti rugi.

5. Jika terjadi perkara Pengadilan Negeri maka debitur wajib membayar biaya perkara, dan debitur dinyatakan bersalah.

6. Dan Melakukan Pelelangan Jaminan Kredit sesuai dengan pasal 15 Undang-Undang Jaminan Fidusia.

Menurut bapak Ir. I Gede Made Jaya Danu, M.M. selaku direktur Bank Perkreditan Rakyat Kita, jika terjadinya wanprestasi BPR Kita tentunya ada akibat hukum untuk nasabah tersebut, baik itu dari yang ringan hingga terberat. Seperti pencatatan arsip 
bahwa nasabah tersebut tidak melakukan itikad baik serta wanprestasi, arsip ini akan dimasukan kedalam SLIK sebagai informasi nasabah tersebut bermasalah, agar tidak terjadinya wanprestasi pada bank lainnya. Sampai dengan yang terberat ialah pelaporan peradilan, pelelangan, dan denda. (Wawancara 19 maret 2019).

\subsubsection{Upaya Kreditur Dalam Penyelesaian Wanprestasi Perjanjian Kredit yang Dilakukan Oleh Pihak Debitur dengan Jaminan Fidusia pada Bank Perkreditan Kita}

Upaya yang dilakukan untuk menyalamatkan kredit macet diatur pada dalam Surat Edaran Bank Indonesia Nomor 26/4/BPPP tahun 1993 tentang Kualitas Aktiva Produksi dan Pembentukan Penyisihan Penghapusan Aktiva Produksi tertanggal 29 mei 1993 yang memiliki prinsip penanganan yaitu dengan :

1. Penjadwalan Kembali (Rescheduling)

Merupakan suatu upaya hukum untuk melakukan perubahan terhadap beberapa syarat perjanjian kredit, baik itu berupa memperpanjang waktu pembayaran kredit maupun penyerahan angsuran, atau jika perlu penambahan kembali biaya kredit tersebut.

2. Persyaratan Kembali (reconditioning)

Merupakan perubahan sebagian maupun keseluruhan persyaratan perjanjian, yang tidak dibatasi kepada perubahan jadwal angsuran, atau jangka waktu kredit. Upaya yang dilakukan itu seperti bunga dijadikan utang pokok, penundaan pembayaran bunga hingga waktu tertentu, penurunan pada suku bunga, serta pembebasan 
bunga jika debitur tidak mampu lagi memenuhi kewajibannya.

\section{Penataan Kembali (Restructuring)}

Merupakan upaya bank kepada debitur dengan menambah modal usaha yang mempertimbangkan usaha debitur yang ditambahkan modalnya memang masih layak.

4. Penyitaan Jaminan

Merupakan Jalan terakhir bank dalam mengurangi kerugiannya apabila nasabah sudah tidak memiliki itikad baik dan/atau tidak memiliki kemampuan untuk membayar utangnya. Pada hal ini bank melakukan upaya pelelangan akan tetapi banyak bank yang menyalah artikan penyitaan jaminan. ada tahapan - tahapan untuk mengambil jaminan pada debitur tersebut. 6 Terutamanya pada jaminan fidusia yang rata - rata berupa kendaraan mobil maupun motor. Didalam Pasal 15 ayat (2) Undang - Undang Fidusia "Sertifikat Jaminan Fidusia sebagaimana dimaksud dalam ayat (1) mempunyai kekuatan eksekutorial yang sama dengan putusan pengadilan yang telah memperoleh kekuatan hukum tetap". ${ }^{7}$ Jadi pada dasarnya jika debitur menolak jaminannya disita. Maka bank seketika itu tidak bisa mengeksekusi/menyita jaminan secara langsung ataupun menggunakan debtcollector karena ketentuan yang sesuai pada Pasal 15 ayat 2. Kreditur mengajukan permohonan ke Pengadilan Negeri dimana Pengadilan Negeri membuat putusan yang kemudian penetapannya itu

\footnotetext{
${ }^{6}$ Ni Made Ayako Dwiyani, 2017 "Wanprestasi Dalam Pelaksanaan Perjanjian Kredit Dengan Jaminan Fidusia Pada PT. Federal International Finance Group Cabang Kuta Raya" Kertha Semaya, Vol. 05, No. 02, April 2017, h. 7. ojs.unud.ac.id, URL: https://ojs.unud.ac.id/index.php/kerthasemaya/article/view/30124 diakses tanggal 25 juni 2019, pukul 03.34

${ }^{7}$ Trisadini Prasastinah Usanti dan Leonora Bakarbessy, 2014, Hukum Jaminan, Revka Petra Media, Surabaya, h. 71.
} 
digunakan untuk eksekusi yang didampingi penegak hukum. Lainhalnya jika debitur memberikan jaminannya ke kreditur maka hal yang dilakukan adalah sebagai berikut :

a. Kesepakatan kedua belah pihak, jadi baik kreditur maupun debitur sepakat menjual kendaraan tersebut dengan cara diiklankan, kemudian hasil penjualan kendaraan tersebut akan dibayarkan ke kreditur, apabilan hasil penjualan kurang debitur wajib menambahkan kekurangan, dan apabila lebih kreditur wajib mengembalikan hasil penjualan kendaraan tersebut.

b. Debitur melakukan penjualan jaminan berupa kendaraan dimana hasil dari penjualan tersebut dilaporkan debitur ke kreditur. Serta sebaliknya kreditur melakukan penjualan kendaraan dan hasil penjualan dilaporkan ke debitur. ${ }^{8}$

Ada 7 tahapan yang harus dilalui dalam prosedur pelelangan perjanjian kredit antara lain :

1. Tahapan 1 dalam pemberian kredit pihak bank harus melakukan analisis terhadap debitur yang akan meminjam kredit, dalam hal ini pihak bank perlu juga menerapkan prinsip 5C (Character, Capacity, Collacteral, Capital, Condition Of Economy) sebagai dasar analisis kredit dan juga dasar menentukan apakah kreditur tersebut layak diberikan kredit atau tidak.

\footnotetext{
${ }^{8}$ I Made Adi Dwi Pranatha "Penyelesaian Wanprestasi Dalam Perjanjian Kredit Bank Pada PT. Bank Negara Indonesia Kantor Cabang Unit Singaraja" Kertha Semaya, Vol. 04 No. 03, April 2016, h. 4 ojs.unud.ac.id, URL: https://ojs.unud.ac.id/index.php/kerthasemaya/article/view/20418 diakses tanggal 25 juni 2019, pukul 03.34
} 
2. Tahapan 2 merupakan tahapan pelunasan kredit tersebut, pada tahapan ini ada 2 kemungkinan yang akan terjadi yaitu pelunasan kredit berjalan lancar atau pelunasan kredit tidak berjalan lancar. Jika pelunasan kredit berjalan lancar bank akan mengapresiasi debitur tersebut dan tidak hanya itu pada SLIK (Sistem Layanan Informasi Keuangan) data debitur tersebut akan baik dan memiliki kesempatan yang besar untuk meminjam kembali. Lain halnya jika pelunasan kredit tidak berjalan lancar maka bank akan melakukan tindakan lanjut berupa pengawasan pelunasan kredit serta penilaian terhadap kredit tersebut jika berpotensi kredit macet.

3. Tahapan 3 merupakan tindakan bank dalam memperingan beban debitur untuk melunasi kreditnya. Ada 3 cara yang dilakukan bank untuk meringankan beban nasabah yaitu dengan 3R (Rescheduling, Restructuring, Reconditioning) dilakukannya penjadwalan kembali, penataan kembali, dan persyaratan kembali upaya ini menjadi acuan agar nasabah mampu dan mau melunasi kembali kredit yang telah macet tersebut, akan tetapi jika hal tersebut dianggap tidak bisa memberikan solusi maka bank harus membuat keputusan melelang jaminannnya. Pelelangan Jaminan Fidusia ada pada Pasal 15 ayat 3 Undang - Undang Jaminan Fidusia No 49 Tahun 1999 Dalam pelelangan perlu dilakukannya Pra Lelang Pengajuan permohonan tertulis perihal eksekusi benda jaminan diajukan kepada Kepala Kantor Pelayanan Kekayaan Negara dan Lelang (KPKNL), yang merupakan instansi pemerintah yang berada di bawah Direktorat Jenderal Kekayaan Negara pada Kementerian Keuangan. Dalam hal ini Bank juga dapat meminta 
menggunakan jasa Pra Lelang dari Balai Lelang Swasta. KPKNL/Balai Lelang Swasta akan melakukan pemeriksaan kelengkapan dokumen lelang, yaitu termasuk namun tidak terbatas pada Perjanjian Kredit, Sertipikat Hak Tanggungan, Bukti perincian utang jumlah debitur, bukti peringatan wanprestasi kepada debitur, bukti kepemilikan hak, bukti pemberitahuan pelelangan kepada debitur. Setelah dokumen tersebut dianggap lengkap, maka KPKNL akan mengeluarkan penetapan jadwal lelang secara tertulis kepada Bank. Bank akan melakukan Pengumuman Lelang, Jika barang yang dilelang adalah barang tidak bergerak dan dengan barang bergerak, maka pengumuman dilakukan sebanyak 2 kali, berselang 15 hari. Pengumuman pertama dapat dilakukan melalui pengumuman tempelan yang dapat dibaca oleh umum atau melalui surat kabar harian. Tetapi pengumuman kedua harus dilakukan melalui surat kabar harian dan dilakukan 14 hari sebelum pelaksanaan lelang. Jika barang yang dilelang adalah barang bergerak, pengumuman dilakukan 1 (satu) kali melalui surat kabar harian paling singkat 6 (enam) hari kalender sebelum pelaksanaan lelang.

4. Tahapan 4 merupakan sebuah persetujuan maupun kesepakatan seorang debitur untuk melelangkan jaminannya hal ini bisa dikatakan sebagai (Pelelangan Non Eksekusi Suka Rela) artinya debitur setuju untuk melelangkan jaminannya baik debitur itu sendiri yang melelangkan maupun pihak dari Bank.

5. Tahapan 5 merupakan tindakan penolakan pelelangan jaminan oleh debitur dalam hal ini ada 2 tindakan yang 
dapat dilakukan oleh pihak bank yaitu Pelelangan Eksekusi dan Pelelangan Non Eksekusi Wajib.

6. Tahapan 6 Pelelangan Eksekusi merupakan tindakan bank melalui putusan atau penetapan pengadilan, dokumen dokumen serta peraturan perundang - undangan, dalam hal ini pada pasal 29 Jaminan Fidusia yang mengatur tentang Eksekusi Jaminan Fidusia.

7. Tahapan 7 Pelelangan Non Eksekusi Wajib merupakan tindakan bank melakukan pelelangan barang jaminan berdasarkan peraturan yang berlaku. Baik itu pada peraturan Jaminan Kredit mapaun peraturan Jaminan Fidusia.

Menurut bapak Ir. I Gede Made Jaya Danu, M.M. selaku direktur Bank Perkreditan Rakyat Kita memberikan penjelasan yang secara rinci upaya penyelesaian perjanjian kredit dalam hal debitur wanprestasi. Jika suatu saat debitur jatuh tempo dalam pembayaran dan tidak memiliki niatan untuk memenuhi kewajibannya, maka BPR Kita akan membuat sebuah laporan keterlambatan pembayaran, hal ini akan tertera pada SLIK (Sistem Layanan Informasi Keuangan) yang juga menyebabkan cideranya reputasi debitur tersebut, hal ini dapat membuat debitur tersebut tidak bisa di terima pada bank lainnnya. Pihak BPR Kita dalam menangani kasus ini akan memberikan surat pemberitahuan keterlambatan pengangsuran dana. jika sudah melawati batas waktu yang di tentukan dan tidak ada respon dari debitur maka BPR Kita Mengeluarkan surat baru berupa surat teguran. Jika tidak adanya respon juga dari surat teguran tersebut maka bank menurunkan status kredit debitur tersebut menjadi rendah atau macet. BPR Kita akan memberikan SP 1 hingga yang tertinggi SP 3. (Wawancara 19 maret 2019). 


\section{PENUTUP}

\subsection{Kesimpulan}

Dari 2 rumusan diatas dapat disimpulkan Akibat hukum terhadap nasabah yang melakukan wanprestasi khususnya pada PT. BPR Kita Badung menerapkan pada prinsip ganti rugi dan pengambil alihan jaminan sebagai tindakan hukum. Penyelesaian terhadap nasabah yang melakukan wanprestasi dilakukan dengan berbagai macam tahap. Tahapan - tahapan ini harus dilaksanakan sesuai dengan prosedur yang ada seperti tahapan awal jika ada salah satu nasabah bank memiliki potensi tidak memenuhi kewajiban pembayaran maka bank akan melakukan penganalisaan lebih lanjut, setelah itu jika nasabah tersebut melakukan wanprestasi, bank akan melakukan upaya pelelangan pada jaminan.

\subsection{Saran}

Ada beberapa saran yang dikemukakan PT.BPR Kita dalam hal ini harus lebih berhati-hati dalam menganalisis pemberian kredit agar tidak terjadinya kesalahan maupun wanprestasi Tindakan pendekatan secara kekeluargaan yang dilakukan PT.BPR Kita Badung untuk menyelesaikan permasalahan wanprestasi kredit ini sangatlah baik. Akan tetapi ada 1 point penting yang harus di kedepankan yaitu harus memiliki kesigapan dan usaha yang lebih keras agar tahun yang akan datang dapat mengurangi wanprestasi perjanjian kredit ini. 


\section{Buku - Buku :}

Ahmadi Miru dan Sakka pati, 2016, Hukum Perikatran Penjelasan Makna Pasal 1233 sampai 1456 BW, Rajawali Pers, Jakarta.

Hermansyah, 2006, Hukum Perbankan Nasional Indonesia, Kencana, Jakarta.

M. Bahsan, 2015, Hukum Jaminan dan Jaminan Kredit Perbankan Indonesia, PT Raja Grafindo Persada, Jakarta.

Sentosa Sembiring, 2012, Hukum Perbankan, CV Mandar Maju, Bandung.

Trisadini Prasastinah Usanti dan Leonora Bakarbessy, 2014, Hukum Jaminan, Revka Petra Media, Surabaya.

Zainuddin Ali, 2009, Metode Penelitian Hukum, Sinar Grafika, Jakarta.

\section{Peraturan Perundang - Undangan :}

Undang-Undang Dasar Republik Indonesia Tahun 1945

Kitab Undang - Undang Hukum Perdata. Terjemahan R.Subekti dan R.Tjitrosudibio, 2009, Balai pustaka, Jakarta.

Undang -Undang No 10 Tahun 1998 perubahan dari Undang Undang No 7 Tahun 1992 tentang Perbankan.

Undang - Undang Republik Indonesia No 42 Tahun 1999 tentang Jaminan Fidusia

\section{Jurnal Ilmiah}

Ni Made Ayako Dwiyani, 2017 "Wanprestasi Dalam Pelaksanaan Perjanjian Kredit Dengan Jaminan Fidusia Pada PT. Federal International Finance Group Cabang Kuta Raya" Kertha Semaya, Vol. 05, No. 02, April 2017, h. 7. ojs.unud.ac.id, URL: 
https://ojs.unud.ac.id/index.php/kerthasemaya/article/view $\lcm{30124}$ diakses tanggal 25 juni 2019, pukul 03.34

I Made Adi Dwi Pranatha "Penyelesaian Wanprestasi Dalam Perjanjian Kredit Bank Pada PT. Bank Negara Indonesia Kantor Cabang Unit Singaraja" Kertha Semaya, Vol. 04 No. 03, April 2016, h. 4 ojs.unud.ac.id, URL: https://ojs.unud.ac.id/index.php/kerthasemaya/article/vie $\underline{\mathrm{w} / 20418}$ diakses tanggal 25 juni 2019, pukul 03.34 